\title{
Bioethanol Production from Several Tropical Wood Species using Simultaneous Saccharification and Fermentation Processes
}

\author{
M. Daud, Wasrin Syafii, and Khaswar Syamsu
}

\begin{abstract}
The study was conducted to determine the best method of hydrolysis (saccharification) and fermentation for bioethanol production using simultaneous saccharification and fermentation process. Three different tropical wood species namely gmelina wood (Gmelina sp.), pine wood (Pinus merkusii) and oil palm (Elaeis guineensis Jacq.) were pre-treated using kraft process and then converted into bioethanol using simultaneous saccharification and fermentation (SSF) processes. The pulp produced by kraft process was analized to determine their chemical properties before treatments. SSF was performed in 500 $\mathrm{ml}$ fermentors with total slurry of $200 \mathrm{ml}$. The substrate and nutrient media were autoclaved $\left(121^{\circ} \mathrm{C}\right.$ and $\left.20 \mathrm{~min}\right)$. The samples diluted to $2.5 \%(\mathrm{w} / \mathrm{v})$ of total slurry were used as substrate. The enzyme preparation used commercial cellulase enzyme. The amount of cellulase added was 4 and $8 \%(\mathrm{w} / \mathrm{w})$ of dry mass of samples. All SSF process was conducted by inoculating yeast Saccharomyces cerevisiae into fermentor in the amount of $10 \%$ (v/v) $1.5 \times 10^{9} \mathrm{CFU} / \mathrm{cc}$. The SSF experiments run for $96 \mathrm{~h}$, and the data were investigated periodically every $24 \mathrm{~h}$. The results showed total sugar and reducing sugar tended to decrease with time of inoculation whereas ethanol concentration increases significantly. The growth of yeast Saccharomyces cerevisiae tended to incease in initial inoculation and decrease by the end of inoculation. The best method of hydrolysis (saccharification) and fermentation using SSF process for all tropical wood species tested were using cellulase $8 \%$ of dry mass (DM) and 10\% (v/v) of Saccharomyces cerevisiae which produced bioethanol with concentration of $0.98 ; 0.57$ and $0.51 \%$ for gmelina, pine and oil palm respectively and produced yields $11.21,5.85$ and $3.20 \%$, in that order.
\end{abstract}

Keywords: Bioethanol, simultaneous saccharification and fermentation, tropical wood species, cellulase, Saccharomyces cerevisiae.

\section{Introduction}

Due to increasing population and economic growth, energy consumption in the world has increased significantly. According to Prihandana et al. (2007), energy demand in the world is supposed to rise by $1.7 \%$ by 2030 , while in Asian region particularly, energy demand will increase by $2.8 \%$. Increasing energy demand in Asian region is caused by rapid economic and industrial development particularly in China and India and other developing countries such as Indonesia.

However, increasing demand of fossil fuels will likely to cause diminishing of world fuels reserve, which may lead to the scarcity of this type of fuels while also cause the price to increase dramatically. Moreover, huge consumption of fossil fuels can cause serious problem. The release of carbon dioxide $\left(\mathrm{CO}_{2}\right)$ from vehicle and other industries is one of the largest potential contributors to global warming. Fortunately, important progress in research and development aimed at obtaining liquid fuels from biomass has proven that this major potential problem can be attenuated. Development of alternative energy such as biofuels become important to reduce this problems.

There are many resources which can be processed into biofuels in Indonesia such as biodiesel which can be produced from Jatropha curcas, Elais guineensis, and Callophyllum inophyllum and also bioethanol from cane sugar and molasses. Bioethanol with concentration of 99.5\% is called Fuel Grade Ethanol (FGE). It currently can be blended typically at $10 \%$ levels with gasoline and also called gasohol (Prihandana et al. 2007).

Utilization of bioethanol as transportation fuel and as a gasoline supplement has been proved to be more environmentally friendly. Bioethanol is a clean-burning, high octane fuel that can readily substitute gasoline and its combustion results in significant reductions of toxic emissions such as formaldehyde, benzene and 1.3 butadiene, while blending ethanol with gasoline can increase the octane of the mixture and can reduce carbon monoxide emissions by $10 \sim 30 \%$. When ethanol is produced from renewable sources such as biomass it can both decrease urban air pollution and reduce the accumulation of carbon dioxide, so called green house gases. Thus, replacement of gasoline with ethanol, derived from renewable biomass feedstocks that sequester $\mathrm{CO}_{2}$ during growth, is expected to reduce $\mathrm{CO}_{2}$ emissions by 90 $100 \%$. (Bruce and Palfreyman 1998). Besides that, development of biofuels in Indonesia is expected to assure availability of new and renewable energy resources, increase the economic value of forest and also can reduce the proverty and unemployment in Indonesia.

Nowadays, bioethanol production in Indonesia is focused on sugar crops including sugar cane and sugar beets and also starch crops, including wheat, potatoes and sweet potatoes. Current production of fuel etanol is often based on excess agricultural production and it is generally recognized that this volume is too small in comparison with the anticipated levels of production required for total 
conversion of transportation fuel markets from gasoline to ethanol. It is also apparent that there is a potential for competition with food production for both the sugar and starch feed-stocks and that prime agricultural lands normally required to produce foodstuffs should not be diverted for fuel production. Therefore, bioconversion of lignocellulosic biomass into bioethanol is very important to be developed in Indonesia because this resources is more economical. Biomass resources obtained from lignocellulosic materials such as agricultural and forestry residues, municipal solid waste, and various industrial wastes are still not well utilized, hence often present disposal problems. These residues can be found easily in Indonesia. Furthermore, woody and herbaceous energy crops can be planted and underutilized land can be employed to support indigenous production of such forms of biomass. Not only it is renewable, this biofuels can also reduce gases emission which potentially can cause global warming (Bruce and Palfreyman 1998; Smith et al. 2003; Samejima 2008).

There are many recently studies related to bioethanol production from lignocellulosic biomass (Ingram et al. 1999; Boussaid et al. 1999; Spagnuolo et al. 1999; Smith et al. 2003; Samejima, 2008). Some of lignocellulosic biomasses that have been investigated are bagasse (Martinez et al. 2000), straw (Neureiter et al. 2002) and wood (Boussaid et al. 1999; Stenberg et al. 1998). Lignocellulosic biomass is typically composed of a complex mixture of three polymers that is cellulose, hemicelluloses and lignin and a small amount of other compounds that are loosely termed extractives. Although this biomass is more economical than sugar and starch but the fermentation of sugars derived from lignocellulosic feedstocks has proven to be more of a process design and operating challenge than traditional sugar or starch based process (Bruce and Palfreyman 1998; Miyafuji et al. 2003). Therefore, bioconversion of lignocellosic biomass into ethanol needs process optimization especially in pretreatment, saccharification, fermentation, and distillation (Smith et al. 2003; Samejima 2008).

Beside process optimization of bioethanol production, it is important to produce bioethanol in low cost. Some of the methods to minimize production cost are producing bioethanol using simultaneous saccharification and fermentation (SSF) process (Wyman 1996) or using lignocellulosics biomass that is more economical, abundant and can be planted easily. It is also important to increase yield of ethanol by converting both celluloses and hemicelluloses into ethanol.

The evaluation and identification of yeasts for SSF application has generally taken a two-pronged approach. Many investigators concentrated on the identification of thermotolerant and ethanol-tolerant yeast strains which could ferment only glucose, while other groups tried to identify and isolate cellobiose-fermenting yeast strains which could be applied specifically to SSFs of cellulosic subtrates. It is also possible to mix the cultures of cellobiose-fermenting yeast and ethanol tolerant, glucosefermenting yeasts and gain supplementation with $\beta$ glucosidase and ethanol tolerance at the same time. An ideal yeast should of course be able to ferment cellobiose and sugars obtained from cellulosic biomass or even cellulolytic itself. A microorganism has been known and often proposed as the best microrganism for SSF of cellulosic hydrolysates is Saccharomyces cerevisiae with cellulose enzymes from Aspergillus niger (Saddler 1993).

Evaluation and economical optimization of bioethanol depend on many factors such as materials and isolate. Due to strong interdependent of subprocess steps, it has been extremely difficult to identify the relative technical or economic merits of each of subprocess variation and their subsequent influence on the final production cost of ethanol. This study was conducted to determine the best method of hydrolysis (saccharification) and fermentation in bioethanol production using three different tropical wood species namely gmelina wood (Gmelina arborea Roxb.), pine wood (Pinus merkusii) and oil palm (Elaeis guineensis Jacq.). These three woods were pretreated using kraft process and then were converted into bioethanol using simultaneous saccharification and fermentation (SSF) processes.

\section{Materials and Methods}

\section{Materials}

Wood meals were derived from three kinds of tropical wood species which is abundant and generally planted in Indonesia, gmelina (Gmelina arborea Roxb.), pine (Pine merkusii Jung. et de Vr.), and palm oil (Elaeis guineensis Jacq.). Saccharomyces cerevisiae and commercial cellulase enzyme were obtained from Sigma Aldrich, Japan (0.83 $\mathrm{U} / \mathrm{mg}$ ). The reagents used were $\mathrm{NaOH}, \mathrm{Na}_{2} \mathrm{~S}$, acetic acid $\left(\mathrm{CH}_{3} \mathrm{COOH}\right)$, ethanol $\left(\mathrm{C}_{2} \mathrm{C}_{5} \mathrm{OH}\right)$, benzene $\left(\mathrm{C}_{6} \mathrm{H}_{6}\right)$, sulfuric acid $\left(\mathrm{H}_{2} \mathrm{SO}_{4}\right)$, sodium chloride $\left(\mathrm{NaClO}_{2}\right)$, nitric acid $\left(\mathrm{HNO}_{3}\right)$ $3.5 \%$, and $\mathrm{Na}_{2} \mathrm{SO}_{3}$. Other materials used were aluminium foil, aquadest, glucose, filter paper, tissue, cotton, eppendorf tube, $30 \mathrm{~mL}$ sample bottle, Potatoe Dextrose Agar (PDA), alcohol 96\%, yeast extract, malt, pepton, glucose, 3,5-dinitrosalisilat, aliumnatriumtartrat-tetrahydrat $\left(\mathrm{C}_{4} \mathrm{H}_{4} \mathrm{KNaO}_{6} .4 \mathrm{H}_{2} \mathrm{O}\right)$, phenol, Na-Metabisulfit, $\mathrm{HCl}$, fenolptalein indicator, sytrate buffer $\mathrm{pH} \mathrm{5}$, and for media nutritions were $\left(\mathrm{NH}_{4}\right)_{2} \mathrm{HPO}_{4}$ and $\mathrm{MgSO}_{4} .7 \mathrm{H}_{2} \mathrm{O}$.

The instruments used in this study were hammer mill, 40 mess sieves, fermentor, glass rod, glass filter, weights, oven, water bath, autoclave, sentrifuge, rotary bioreactor tray, $\mathrm{pH}$ meters, loops, $250 \mathrm{~mL}$ Erlenmeyer flask, jars, beaker, volumetric flask, rod, spray bottle, pipette, funnel, thermometer, hose, pan, stove, hot plate, spirit lamp, instrument for fermentation incubator, Shimadzu $X$ ray difractometer, Spectrofotometer, and GC (Gas Chromatograph). 


\section{Methods}

Sample Preparation. Three different fresh chopped tropical wood species namely gmelina wood (Gmelina sp.), pine wood (Pine merkusii) and oil palm (Elaeis guineensis Jacq.), free from bark were used in this study. The chips were milled and then sieved into size of $2 \sim 4 \mathrm{~mm}$ in thickness, \pm $3 \mathrm{~cm}$ in long and $2 \sim 3 \mathrm{~cm}$ in width. The wood chips were then oven dried and their water contents before treatments were measured. The yeast was cultivated under sterile conditions using Potatoe Dextrose Agar (PDA). This isolates were cultivated in YMGP (Yeast Malt Glucose Pepton) prior to being used in the SSF experiments.

Pre-treatments. The wood chips (about $200 \mathrm{~g}$ dry mass) were pretreated using kraft process. The treatment was conducted using three levels of alkalinity (active alkali) (16, 18 and $20 \%$ ) and two levels of sulfidity namely $20 \%$ and $25 \%$. Chemical property, yield and kappa number of the pulp produced were determined prior to SSF experiments.

Simultaneous Saccharification and Fermentation (SFF). The SSF run was performed in $500 \mathrm{ml}$ fermentors filled up with total slurry of $200 \mathrm{ml}$. The substrate and nutrient media were autoclaved at temperature of $121^{\circ} \mathrm{C}$ and $20 \mathrm{~min}$. A slurry containing $2.5 \%$ (w/v) pulp density was used as substrate while a commercial cellulose enzyme was used as enzyme preparation. The amount of cellulase added were $4 \%$ and $8 \%(\mathrm{w} / \mathrm{w})$ dry mass of samples. All SSF processes were inoculated with 10\% (v/v) yeast Saccharomyces cerevisiae $\left(1.5 \times 10^{9} \mathrm{CFU} / \mathrm{cc}\right)$. The SSF experiments run for 96 h. Total sugar, reducing sugar, growth of Saccharomyces cerevisiae and ethanol concentration were measured periodically every $24 \mathrm{~h}$.

\section{Results and Discussion}

\section{Chemical Properties}

Non Structural Components. Extractives are compounds of diverse nature with low to moderately high molecular weights which by definition are soluble (extracted) in organic solvents or water. They impart color, odor, taste and occasionally, decay resistance to wood. There are hundreds of compounds in the extractives of a single sample of wood.The composition of extractives varies widely from species to species within different parts of the same wood species. The extractives soluble in several solvents are listed in Table 1.

In Table 1, soluble extractive of oil palm is the highest among the three wood species in cold and hot water, $\mathrm{NaOH}$ $1 \%$ and ethanol-benzene. Extactives is very important in ethanol production because these can hamper saccharification and fermentation.

Structural Components. The elemental constituents of wood are combined into number of organic polymers: cellulose, hemicelluloses and lignin. Table 2 shows the percentage of dry weight of each raw material.

The major carbohydrate portion of wood is composed of cellulose and hemicellulose polymers with minor amounts of other sugar polymers such as starch and pectin. The combination of cellulose and the hemicellulose is called holocellulose. Table 2 shows that there was significant different of holocellulose content from each raw material. The highest holocellulose content was founded in pine wood and then in gmelina and oil plam, respectively. Holocellulose content is very important in bioethanol production because idealy, bioconversion process of wood to ethanol should be able to convert all of the wood carbohydrates in the feedstock to ethanol.

Table 1. The extractive soluble in several solvents.

\begin{tabular}{lcccc}
\hline Raw material & \multicolumn{4}{c}{ Soluble extractive (\%) } \\
\cline { 2 - 5 } & Cold water & Hot water & NaOH 1\% & Ethanol-Benzene (\%) \\
\hline Pine & 2.45 & 9.53 & 10.33 & 2.54 \\
Gmelina & 7.23 & 8.48 & 16.03 & 7.36 \\
Oil Palm & 12.38 & 15.30 & 43.43 & 38.23 \\
\hline
\end{tabular}

Table 2. The dry weight percentage of each raw material.

\begin{tabular}{lcccc}
\hline Raw Material & Cellulose $(\%)$ & Hemicellulose $(\%)$ & Lignin (\%) & Holocellulose (\%) \\
\hline Pine & 42.40 & 23.25 & 27.50 & 65.65 \\
Gmelina & 47.56 & 16.84 & 27.00 & 64.40 \\
Oil Palm & 25.88 & 16.39 & 12.50 & 42.27 \\
\hline
\end{tabular}


Lignin is a complex and high molecular weight polymer built upon phenylpropane units. Althought composed of carbon, hydrogen, and oxygen, lignin is not a carbohydrate nor even relate to this class of compound. Lignin is difficult to isolate and occurs, in variety of forms. Because of these characteristics, the exact configuration of lignin within wood remains uncertain. Lignin occurs between individual cells and within the cell walls. Between cells, it serves as a binding agent to hold the cells together. Within cell walls, lignin is very intimately associated with celllulose and hemicellulose, and it gives rigidity to the cell. Lignin also credited with reducing dimensional change with moisturecontent fluctuation and making it resistant to decay and insect attact. In Table 2, lignin content of pine is seen to be higher than that of gmelina. It could be the result of softwood characteristics of pine. According to Biermann (1993), lignin content in softwood is higher than that of hardwood. Lignin content in softwood ranges from $25 \sim 35 \%$ while hardwood $18 \sim 25 \%$. The high lignin content of wood can cause wood to be more resistant to convert to ethanol and it needs more chemical material in pretreatment process. According to Nzelibe and Okafoagu (2007), lignin can hamper saccharification process.

Cellulose is present as the main structural component in wood cell walls. Cellulose is a linear polymer of Danhydroglucopyranose units linked by $\beta$ 1-0-4 glycosidic bonds, the number of glucose units per cellulose molecule (the degree of polymerization) averanging between about $8,000 \sim 10,000$ in wood. Table 2 showed that the highest cellulose content is in gmelina then in pine and sengon, respectively. In bioethanol production, the high of cellulose content can be increase yield of sugar in saccharification process and also ethanol yield.

Because of the strong tendency for intra and intermoleculer hydrogen bonding, bundles of cellulose molecules aggregate to microfibrils which form either highly ordered (crystaline) or less oredered (amorphous) regions. These microfibrils pass through several crystalline region (about $60 \mathrm{~nm}$ in length) and, as a result of further aggregation of microfibrils, fiber wall cellulose with a high degree of crystallinity is formed. This also means that cellulose is relatively inert during chemical treatments but also that is soluble only in a few solvents. The most common cellulose solvents are cupriethylenediamine (CED) and cadmiumethylenediamine (Cadoxen), whereas less well known but powerful solvents are $\mathrm{N}$-methylmorpholine $\mathrm{N}$ oxide and lithium chloride/dimethylformamide. Table 3 shows degree of crystallinity of cellulose. The lowest of degree of crystallinity is founded in gmelina.

In bioethanol production, reactivity of pulp with chemicals is depended on degree of crystallinity of cellulose. Region of crystallinity develop which are difficult to penetrate by solvents or reagent. By contrast, the relatively more amorphous regions are readily penetrated and are therefore more susceptible to hydrolysis reactions. So the lower of crystallinity of cellulose make raw material more susceptible to hydrolysis and fermentation for bioethanol production.

Althought glucose is the primary sugar produced in the process of photosynthesis, it is the only one. Other six carbon sugars, such as galactose and mannose, and five carbon sugar, such as xylose and arabinose, are also manufactured in the leaves. These and other sugar derivatives such as glucoronic acid, along with glucose, are used with depeloving cell in synthesizing lower molecular weight polysaccarides called hemicellulose. Most of the hemicelluloses are branched chain polymers. Table 2 showed that the highest hemicellulose content is in pine then in gmelina and oil palm, respectively. In bioethanol production, the high of hemicellulose content can be increase yield of sugar in saccharification process and also ethanol yield.

\section{Pulp Yield}

Pretreatment is the process step required to make the relativily recalcitrant lignocellulosic material more easily digestible to the hydrolytic enzymes while preserving the yield of the original carbohydrates for fermentation. This can be accomplished by various mechanisms such as the removal of the lignin sheath, reduction of cellulose crystalllinity, or by increasing the surface area that is accessible to the enzymes. However, inhibitory breakdown products can be formed if the pretreatment conditions used are too harsh. The nature of the lignocelllulosic substrate used has a major impact on this process step a certain pretreatment, which may be effective with one lignocellulosic substrate, may prove to be ineffective on another. A number of reviews have covered pretreatment into physical, chemical, biological and combination of these methods.

Table 3. Crystallinity of cellulose in several raw material.

\begin{tabular}{cc}
\hline Raw material & Crystallinity of cellulose $(\%)$ \\
\hline Pine & 51.14 \\
Gmelina & 48.38 \\
Oil Palm & 49.61 \\
\hline
\end{tabular}


In this study, method of pretreatment that used was pulping using kraft process with several combinations of alkalinity and sulfidity. In conventional, kraft pulping is a full chemical pulping method using sodium hydroxide $(\mathrm{NaOH})$ and sodium sulfide $\left(\mathrm{Na}_{2} \mathrm{~S}\right)$ to dissolve much of lignin of wood fibers. It is useful for any wood species, gives a high strength pulp, is tolerant to bark, and has an efficient energy and chemical recovery cycle (Biermann 1993). Aktive alkali (alkalinity) is amount $\mathrm{NaOH}$ and $\mathrm{Na}_{2} \mathrm{~S}$ are calculated as sodium equivalents and the concentration of the liquor is expressed as grams of $\mathrm{Na}_{2} \mathrm{O}$ per liter of solution (Gullichsen and Paulopuro 2000).

The yields of pulp show in Figure 1. The yields are ranging from 32.76 and $61.04 \%$. Base on this yield it can be found that each raw material has optimal alkalinity and sulfidity to attain their maximum yield. The highest yield for pine could attain with using alkalinity $18 \%$ and sulfidity $25 \%$. While in gmelina the best kraft method is using alkalinity $20 \%$ and sulfidity $25 \%$ and alkalinity $16 \%$ and sulfidity $20 \%$. In related to bioethanol production, information of alkalinity and sulfidity which produce the highest pulp would be basic information to choose the best pretreatment to remove extractive and lignin with high pulp yield.

\section{Kappa Number}

The measurement of lignin in chemical pulps is a vital tool to monitor the degree of cook (extent of delignification during pulping) or to measure residual lignin before bleaching and between various stages of bleaching to monitor the process, although pulp brightness between bleaching stages is often used to control the bleaching operation. Lignin easily measured indirectly by measuring the amount of an oxidant (such as chlorine or potassium permanganate) consumed by lignin in a sample of pulp of known mass. Methods based on comsumption of potassium permanganate (kappa number and $\mathrm{K}$ numbers) are the most common ones used.

The kappa test is an indirect method for determining lignin by the comsumption of permanganate ion by lignin. The kappa number is the number of milliliters of $0.1 \mathrm{KMnO}_{4}$ comsumed by one gram of pulp in $0.5 \mathrm{~N}$ of sulfuric acid after a ten minute reaction time at $25^{\circ} \mathrm{C}$ under conditions such that one-half of the permanganate remains unreacted. Kappa number of raw material in several combinations of alkalinity and sulfidity showed in Figure 2. The kappa number varies ranging from $4.86 \sim 22.23 \%$. According to Biermann (1993), there are relationship with Klason lignin with kappa number, where Klason lignin (\%) $=0.15 \times$ kappa number. Base on this formula, residual lignin in pulp after delignification ranging from $0.73 \sim 3.33 \%$. Althought in kraft process is aim to remove lignin but pulp still contain by lignin caused by association lignin polysaccharide complexes or lignin-carbohydrate complexes (LCCs). The detailed association of lignin and polysaccharides is not yet fully understood but it is widely believed that linkages between lignin and hemicelluloses components are more likely to pre-dominate that lignin-celllulose bonds. A wealth of evidence is now available to confirm that lignin-xylan complexes can be isolated from hardwoods and ligninmannan and lignin xylan complexes can be isolated from softwood and that the most probable types of covalent linkage are ether linkage, ester linkage and glycosidic bonds.

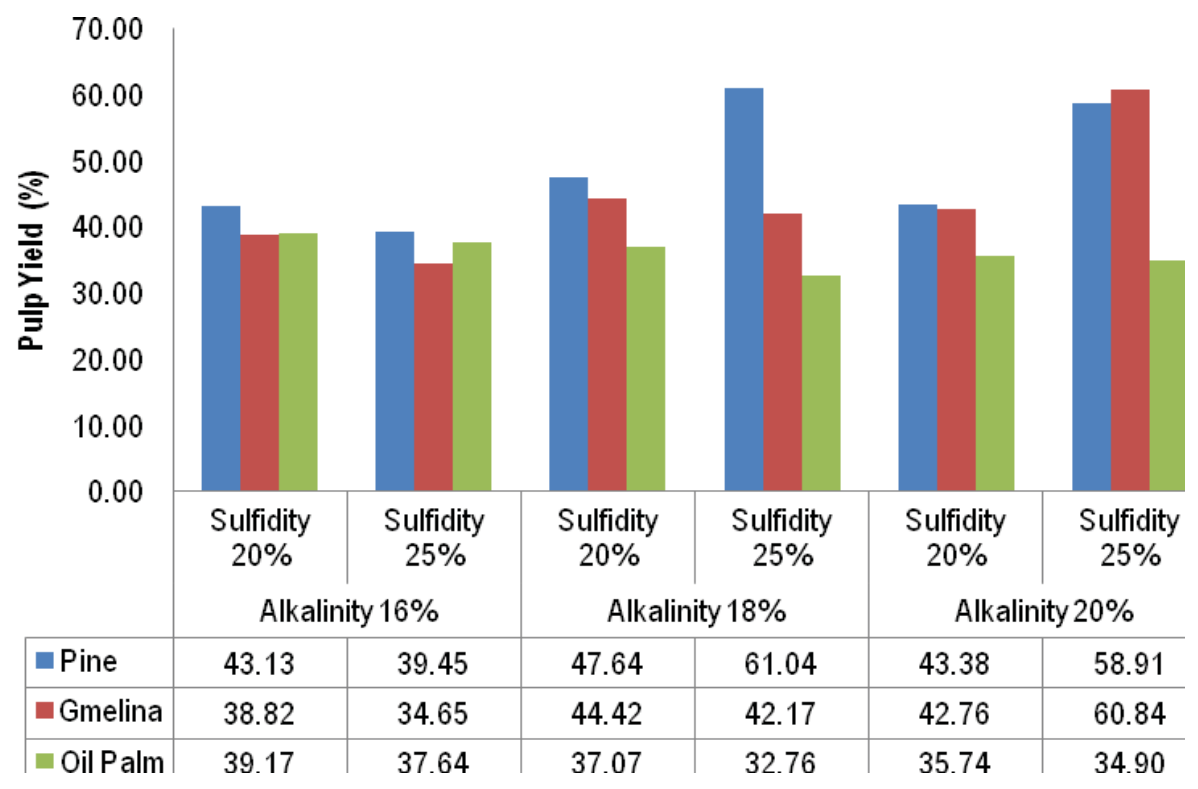

Figure 1. Pulp yield of several wood species. 


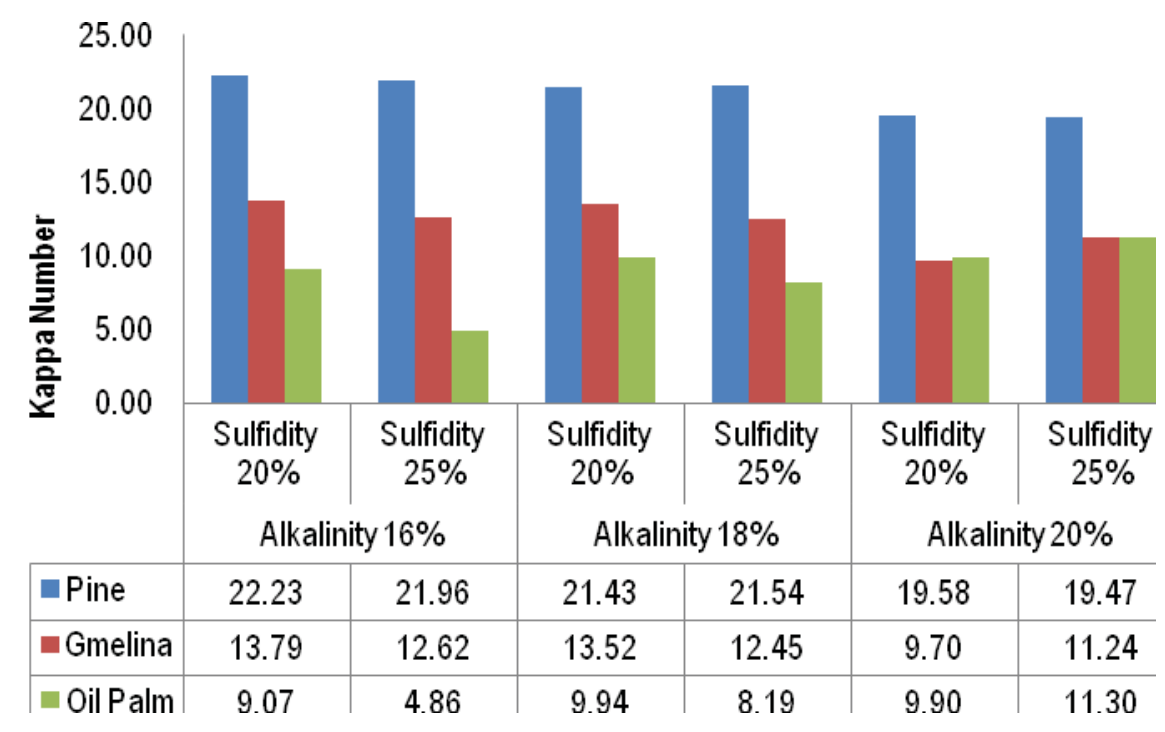

Figure 2. Kappa number of several wood species.

In bioethanol production from lignicellulose material, pretreatment is very important. The most consideration is yield of pulp and residual lignin (kappa number). Base on these consideration, the best pretreatment using kraft process in bioethanol production varies depend on raw material. For pine the best method is using alkalinity $18 \%$ and sulfidity $25 \%$. While in gmelina the best kraft method is using alkalinity $20 \%$ and sulfidity $25 \%$ and alkalinity $16 \%$ and sulfidity $20 \%$. Pulp from these methods is choosed for bioethanol production using simultaneous saccharfication and fermentation. Then, each pulp were determined their chemical properties and the results showed Table 4. There is no significant different holocellulose and cellulose each sample, but in hemicellulose and lignin content there is some significant different. The high cellulose and hemicelluloses important in bioethanol production because could be increase ethanol yield.

\section{Total Content of Sugar}

Total sugar and reducing sugar are important parameter in hydrolysis of lignocelluloses material into sugars. Total content of sugar is all of sugar which produced in hydrolysis both of reducing and non reducing sugar. Total content of sugar is shown in Figure 3 and 4 . Figure 3 shows total content of sugar on SSF using cellulase using celulase enzyme $4 \%(\mathrm{w} / \mathrm{w})$ dry mass and yeast $S$. cerevisiae. Total content of sugar on first hour in pine, gmelina, oil palm were around $575.18,822.50$, and 1332.68 $\mathrm{mg} / \mathrm{L}$, respectively. These sugars which detected in sugar on first hour showed that cellulase can be hydrolysis holocellulose into sugars rapidly. Yang et al. (2005), investigated that cellulase can convert both of cellulose and hemicelluloses rapidly. Adding 60 filter paper unit (FPU)/g cellulase in hydrolisysis of wood has converted $20 \%$ of cellulose one hour after treatment. In general, total content of sugar fluctuated in time of cultivation. That is depending on hydrolysis by cellulase and fermentation sugar into ethanol by yeast $S$. cerevisiae. There is significant increasing of total content of sugar with increasing of cellulase concentration (Figure 4). It caused that concentration of cellulase cause increase ability of cellulase to convert both of cellulose and hemicelluloses into sugars.

Table 4. Chemical properties of pulp for SSF.

\begin{tabular}{lccc}
\hline Raw Material & Celulose (\%) & Hemicellulose (\%) & Lignin (\%) \\
\hline Pine & 85.74 & 10.84 & 3.21 \\
Gmelina & 85.96 & 8.96 & 2.07 \\
Oil Palm & 84.70 & 11.70 & 1.70 \\
\hline
\end{tabular}




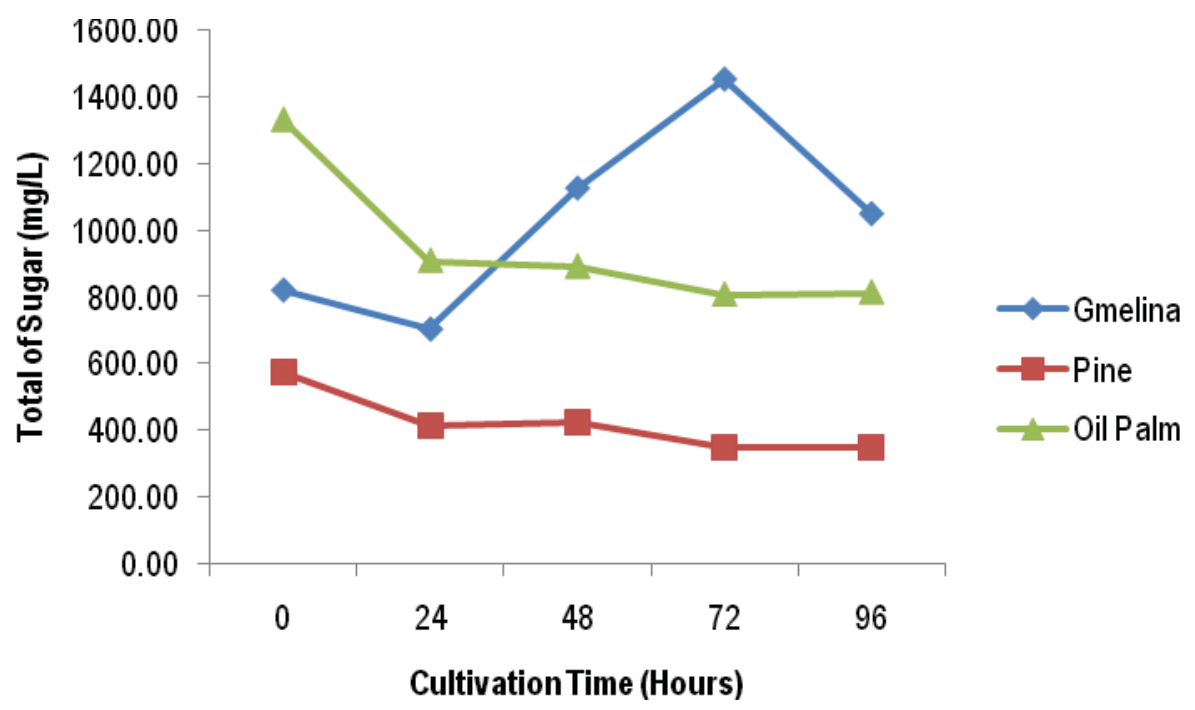

Figure 3. Total content of sugar on SSF using cellulase enzyme $4 \%$.

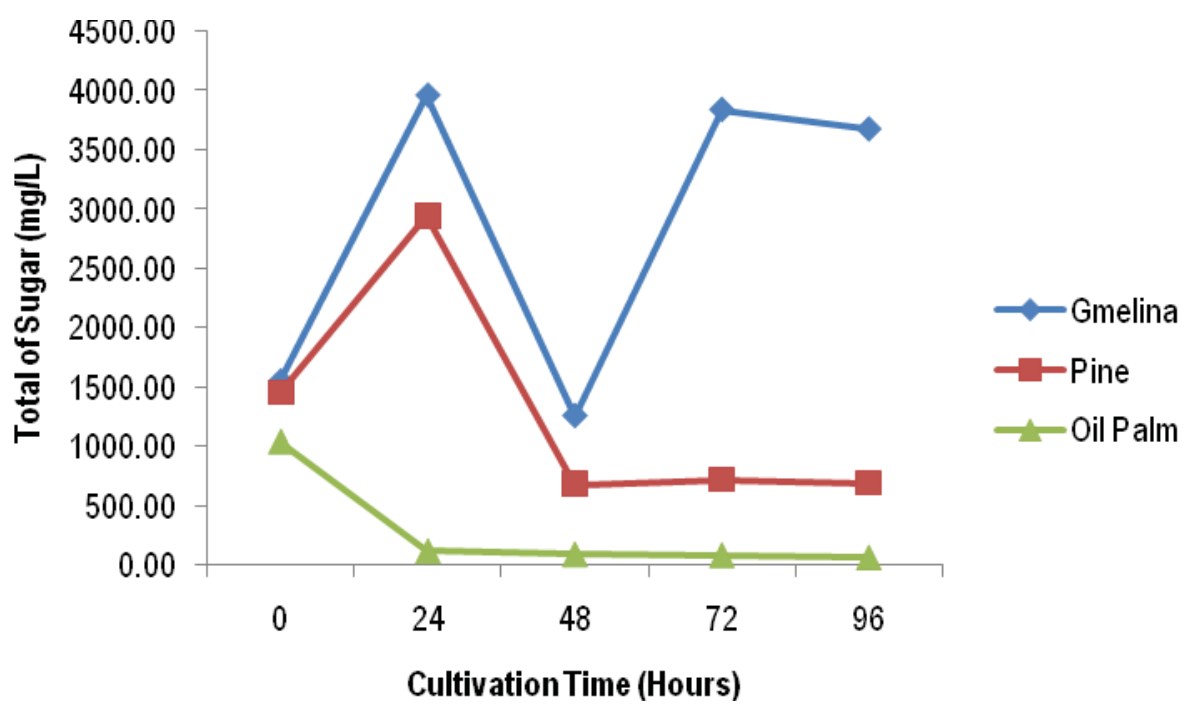

Figure 4. Total content of sugar on SSF using cellulase enzyme $8 \%$.

Reducing Sugar and Ethanol Concentration

The most important process improvement made for the enzymatic hydrolysis of bimass is simulatenous saccharification and fermentation (SSF), which has been improved to include the co-fermentation of multiple sugar substrates. This approach combined the cellulase enzymes and fermenting microbes in one vessel. This enabled a onestep process of sugar production and fermentation into ethanol. Simultaneous saccharification of both carbon polymer, cellulose to glucose, and hemicellulose to xylose and arabinose and fermentation will be carried out by recombinant yeast or the organism which has the ability to utilize both pentose and hexose sugar.

A reducing sugar is any sugar that in a solution, has an aldehyde or a ketone group. This allows the sugar to act as a reducing agent, for example in the Maillard reaction and Benedict's reaction. Figure 5 and 6 showed reducing sugar and ethanol concentration. In general, reducing sugar tended to decrease with time of inoculation whereas ethanol concentration increased significantly. The decreasing of reducing sugar because these sugars convert by Saccharomyces cerevisiae into ethanol production. 


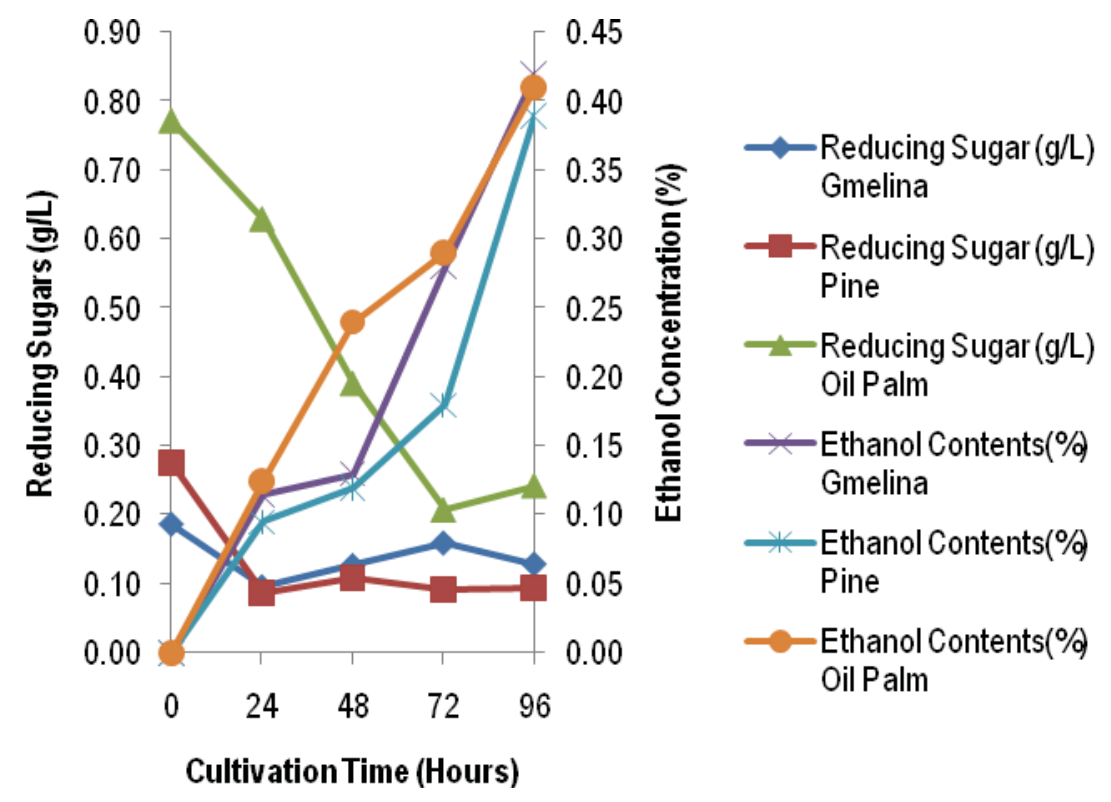

Figure 5. Reducing sugar and ethanol concentration using cellulase $4 \%$.

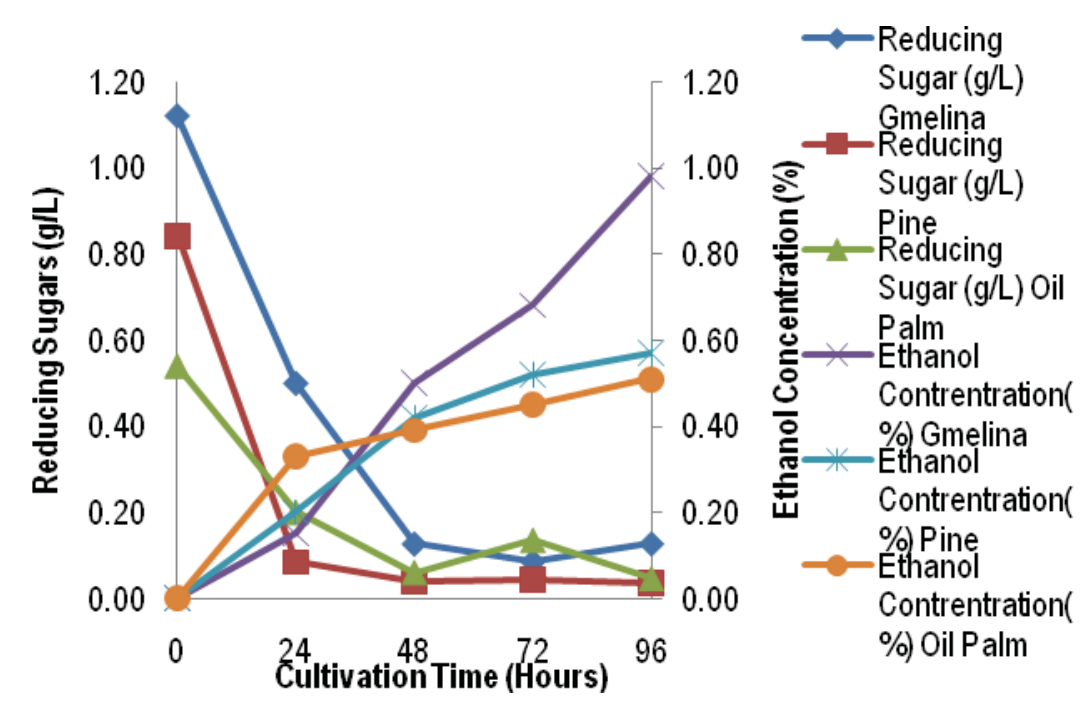

Figure 6 Reducing sugar and ethanol concentration using cellulase $8 \%$.

The Growth of Yeast Saccharomyces cerevisiae

All strains of $S$. cerevisiae can grow aerobically on glucose, maltose, and trehalose and fail to grow on lactose and cellobiose. However, growth on other sugars is variable. It was shown that galactose and fructose were two of the best fermenting sugars. The ability of yeasts to use different sugars can differ depending on whether they are grown aerobically or anaerobically. Some strains cannot grow anaerobically on sucrose and trehalose. All strains can utilize ammonia and urea as the sole nitrogen source, but cannot utilize nitrate since they lack the ability to reduce them to ammonium ions. They can also utilize most amino acids, small peptides and nitrogen bases as a nitrogen source. Histidine, glycine, cystine and lysine are, however, not readily utilized. S. cerevisiae does not excrete proteases so extracellular protein cannot be metabolized. Yeasts also have a requirement for phosphorus, which is assimilated as a dihydrogen phosphate ion, and sulfur, which can be assimilated as a sulfate ion or as organic sulfur compounds like the amino acids methionine and cysteine. Some metals like magnesium, iron, calcium, zinc also are required for good growth of the yeast. 
Figures 7 and 8 show the growth of yeast Saccharomyces cerevisiae. In general, the growth of yeast Saccharomyces cerevisiae tended to incease in initial cultivation and decrease by the end of cultivation. In initial cultivation, sugars still sufficient for growth of yeast Saccharomyces cerevisiae but in the end of cultivation amount of sugars decrease so not sufficient for growth of yeast Saccharomyces cerevisiae.

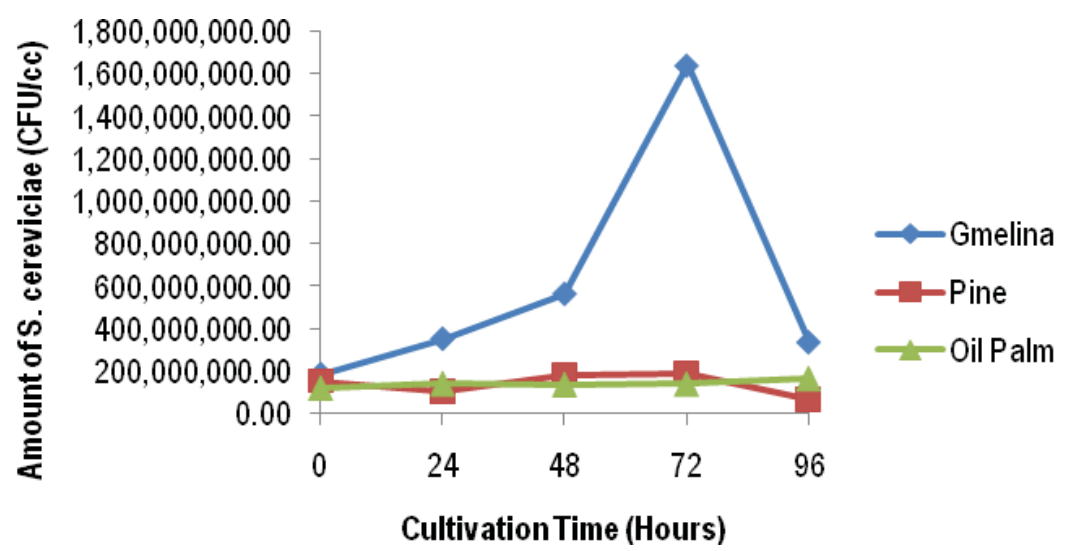

Figure 7. The growth of yeast Saccharomyces cerevisiae using cellulase 4\%.

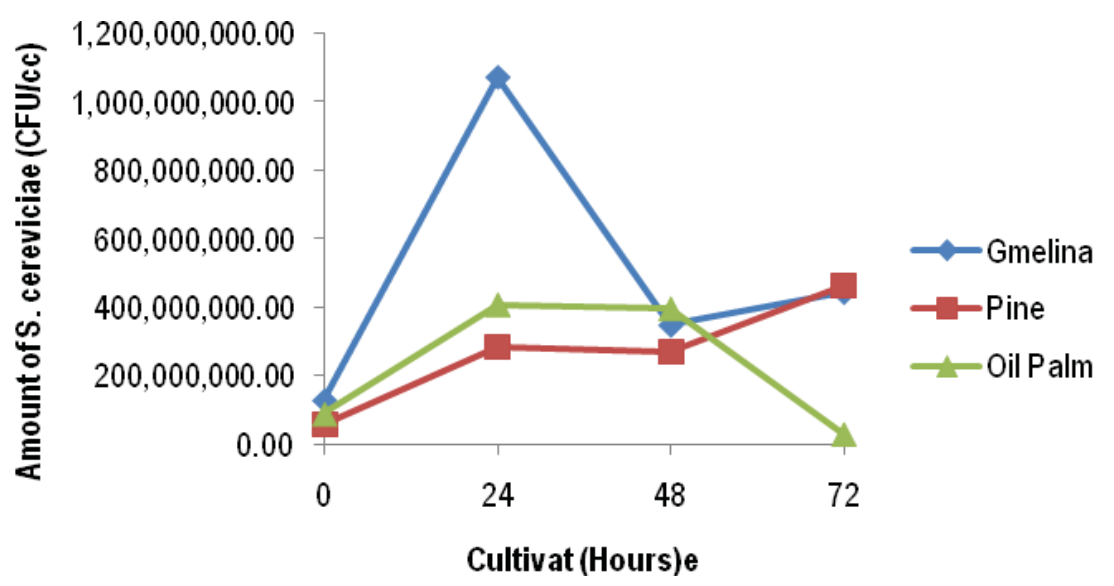

Figure 8. The growth of yeast Saccharomyces cerevisiae using cellulase $8 \%$.

\section{Ethanol Yield}

Ethanol yield in several raw materials is shown in Table 5. The highest ethanol yield is produced in gmelina using cellulase $8 \%$ that is $11.21 \%$. This yield approaches the yield which is produce Stenberg et al. (1998) that is $11.4 \%$ using SSF with pretreatment $\mathrm{SO}_{2} 2.8 \%$ and cellulase enzyme 5 $\mathrm{FPU} / \mathrm{g}$ with substrat concentration of slurry $2 \%(\mathrm{w} / \mathrm{v})$. There is significant different of ethanol yield caused by raw material and cellulase concentration. Gmelina has ethanol yield higher than other because this wood has low degree of crystallinity so their pulp can be coverted to sugars and fermented to ethanol easily. Increasing of cellulase concentration from 4 to $8 \%$ can increase ethanol yield significantly. Where, in gmelina, pine and oil palm ethanol yield increase from 4.29 to $10.02 \%, 5.24$ to $7.65 \%$, and 2.63 to $3.28 \%(\mathrm{v} / \mathrm{v})$, respectively.
Table 5 shows that utilization of biomass from several tropical wood species have potency to produce bioethanol. Ethanol production and productivity of gmelina wood were 238.49 and 3407.59 L/ha per year, respectively. It production higher than ethanol production from Eucalytus grandis which produce $225 \mathrm{~L} /$ ton (Shleser 1994), and also poplar wood which produce yield $283 \mathrm{~L} /$ ton (Schieder 2005), although lower than ethanol production from Aspen wood which produce $354 \mathrm{~L} /$ ton (Olsson and Hagerdal 1996).

Gmelina, pine and oil palm have specific gravity 0.42 , 0.55, and 0.41, respectively (Abdurrohim et al. 2004; Soerianegara and Lemmens 1994). Gmelina produce 304 $\mathrm{m}^{3} / \mathrm{ha}$ at ten years, pine $300 \mathrm{~m}^{3} / \mathrm{ha}$ at 15 years (Soerianegara and Lemmens 1994), and oil palm $606 \mathrm{~m}^{3} / \mathrm{ha}$ at 25 years, so volume of ethanol that produced yang per ton of raw material and also ethanol productivity showed at Table 5. 
Table 5. Ethanol yied of several raw materials.

\begin{tabular}{clcccc}
\hline $\begin{array}{c}\text { Methods of } \\
\text { SSF }\end{array}$ & Wood species & $\begin{array}{c}\text { The higest } \\
\text { ethanol } \\
\text { concentration } \\
(\%)\end{array}$ & Ethanol yield (\%) & $\begin{array}{c}\text { Ethanol production } \\
\text { (L/ton) }\end{array}$ & $\begin{array}{c}\text { Ethanol productivity } \\
\text { (L/ha per year) }\end{array}$ \\
\hline SSF 8\% DM & Gmelina & 0.98 & 10.02 & 238.49 & 3045.08 \\
& Pine & 0.57 & 7.65 & 139.17 & 1530.88 \\
& Oil Palm & 0.51 & 3.28 & 79.9 & 794.04 \\
SSF 4\% DM & Gmelina & 0.42 & 4.29 & 10.21 & 1305.03 \\
& Pine & 0.39 & 5.24 & 95.22 & 1047.45 \\
& Oil Palm & 0.41 & 2.63 & 64.23 & 638.35 \\
\hline
\end{tabular}

Table 6 Productivity of several plants producing bioethanol.

\begin{tabular}{lcrrr}
\hline \multicolumn{1}{c}{ Raw Material } & $\begin{array}{c}\text { Ethanol production } \\
\text { (L/ton) }\end{array}$ & $\begin{array}{c}\text { Production } \\
(\mathrm{kg})\end{array}$ & $\begin{array}{c}\text { Harvest age } \\
\text { (Month) }\end{array}$ & $\begin{array}{c}\text { Ethanol productivity } \\
\text { (L/ha per Year) }\end{array}$ \\
\hline Cassava & 180 & 40 & 9 & 7200 \\
Corn & 385 & 6 & 3.5 & 4620 \\
Sweet Potato & 142 & 20 & 4 & 5680 \\
Sweet Sorgum & 76.7 & 6 & 4 & 920.4 \\
Sorgum Seed & 389 & 4 & 3.5 & 3112 \\
Taro & 142 & 20 & 10 & 2840 \\
\hline
\end{tabular}

Source: Shintawaty (2006)

As comparison, in Table 6 shows productivity of several plants which produce bioethanol. Ethanol production of gmelina (238.49 L/ton) is higher than cassava (180 L/ton) sweet potato (142 L/ton), sweet sorgum (76.7 L/ton), and taro (142 L/ton). In general, productivity of gmelina (3045.08 L/ha per year) higher than sweet sorgum (920.4 L/ha per year) and taro (2840 L/ha per year), but lower than productivity of sorgum seed, corn sweet potato, and cassava with productivity $3112,4620,5680$, and $7200 \mathrm{~L} /$ ha per year, respectively.

\section{Conclusions and Suggestions}

\section{Conclusions}

Production of bioethanol from several wood species using simultaneous saccharification and fermentation was affected by chemical properties of raw material. These chemical properties affected pretreatment, saccharification and fermentation. Yield and kappa number were affected by raw material, alkalinity, and sulfidity. In pretreatment using kraft process, optimum alkalinity and sulfidity for each raw material was $20 \%$ alkalinity and $25 \%$ sulfidity for gmelina, $18 \%$ alkalinity and $25 \%$ sulfidity for pine and $16 \%$ alkalinity and $20 \%$ sulfidity for oil palm. Total sugar and reducing sugar tended to decrease with time of inoculation whereas ethanol concentration increases significantly. The growth of yeast Saccharomyces cerevisiae tended to incease in initial inoculation and decrease at the end of inoculation. The best method of hydrolysis (saccharification) and fermentation on SSF processes for all tropical wood species were using cellulase $8 \%$ of dry mass (DM) and $10 \% \quad(\mathrm{v} / \mathrm{v})$ of Saccharomyces cerevisiae which produced bioethanol with concentration of $0.98,0.57$ and $0.51 \%$ for gmelina, pine and oil palm, respectively and produced yields $11.21,5.85$ and $3.20 \%$ in that order.

\section{Suggestions}

Further study on optimization of simultaneous saccharification using higher concentration of cellulase enzymes or using pure isolate such as Apergillus niger and other yeasts is needed.

\section{References}

Abdurrohim, S.; Y. I. Mandang; U. Sutisna. 2004. Indonesia Wood Atlas Volume III. Bogor: Center of Research and Depelopment of Forest Products Technology, Reseach and Depelopment Department, Forestry Ministry (in Bahasa).

Biermann, C. J. 1993. Essential of Pulping ang Papermaking. California: Academic Press, Inc.

Boussaid, A.; J. Robinson; Y.J. Cai; D.J. Gregg; J. N. Saddler. 1999. Fermentability of the HemicelluloseExploded Softwood (Douglas Fir). Journal of Biotechnology and Bioengineering. 64 (3): 285-289.

Bruce, A.; W. Palfreyman. 1998. Forest Products Biotechnology. Salisbury: International Ltd.

Gullichsen, J.; H. Paulapuro. 2000. Forest Products Chemistry. Paper Making Science and Technology. 
Book 3. Helsinki: Finish Paper Engineers Association and TAPPI.

Ingram, L.O.; P.F. Gomez; X. Lai; M. Moniruzzaman; B. E. Wood; L. P. Yamano; S. W. York. 1999. Metabolic Engineering of Bacteria for Ethanol Production. Journal of Biotechnology and Bioengineering 58 (2): 204-214.

Martinez, A.; M. E. Rodriguez; S.W. York; J. F. Preston; L. O.Ingram. 2000. Effects of $\mathrm{Ca}(\mathrm{OH})_{2}$ Treatments (Overliming) on the Composition and Toxicity of Bagasse Hemicellulose Hydrolysates. Journal of Biotechnology and Bioengineering 69 (5): 526-536.

Miyafuji, H.; H. Danner; M. Nauretier; C. Thomasser; R. Braun. 2003. Effect of Wood Ash treatment Improving the Fermentability of Wood Hydrolysate. Journal of Biotechnology and Bioengineering 84 (3): 390-393.

Neureiter, M.; H. Danner; C. Thomasser; B. Saidi; R. Braun. 2002. Dilute acid Hydrolysis of Sugar Cane Bagasse at Varying Conditions. Journal of Application Biochemical Biotechnology 98: 49-58.

Nzelibe, H.C.; C. U. Okafoagu. 2007. Optimazion of Ethanol Production from Garcinia kola (Bitter Kola) Pulp agrowaste. African Journal of Biotechnology. 6 (17): 2033-2037.

Olsson, L.; B. Hahn-Hagerdal. 1996. Fermentation of Lignocellulosic Hydrolisates for Ethanol Production. Enzymes Micrib Technol. 18:312-331.

Prihandana, R.; K. Noerwijan; P. G. Adinurani; D. Setyaningsih; S. Setiadi; R. Hendroko. 2007. Bioethanol from Cassava: Future Fuels. Jakarta: PT Agromedia Pustaka (in Bahasa).

Saddler, J. N. 1993. Bioconversion of Forest and Agricultural Plant Residues. United Kingdom: C.A.B. International.

Samejima, M. 2008. Scenario of Technical Innovation for Production of Ethanol as Automobile Fuel from Cellulosic Biomass in Japan. Proceedings International Symposium on Wood Scienceand Technology. Harbin, China, 27-29 Sep 2008. Harbin: International Association of Wood Products Societies.

Schieder, D. 2005. Bioethanol Existing Pathways. First European Summer School on Reneable Motor Fuels. Birkenfeld, Germany, 29-31 August 2005.

Shintawaty, A. 2006. Prospect of Biodiesel and Bioethanol Development As Bioenergy Altenatives in Indonesia. Economic Review No. 23th March 2006 (in Bahasa).
Shleser, R. 1994. Ethanol Production in Hawaii: Processes, Feedstocks, and Current Economic Feasibility of Fuel Grade Ethanol Production in Hawaii. Final Report. Hawaii: Department of Business, Economic Development and Tourism, State of Hawaii

Smith, M.T.; P. Sommer; B. K. Ahring. 2003. Purification of Bioetanol Effluent in an UASB Reactor System With Simultaneous Biogas Formation. Journal of Biotechnology and Bioengineering 84 (1): 8-12.

Soerianegara, I.; R.H.M. J. Lemmens. 1994. Plant Resources of South-East Asia. No. 5(1) Timber Trees: Major Commercial Timbers. Bogor, Indonesia: Prosea Foundation.

Spagnuolo, M.; C. Crecchio; M. D.R. Pizzigallo; P. Ruggiero. 1999. Fractionation of Sugar Beet Pulp into Pectin, Cellulose, and Arabinases Combined with Ultrafiltration. Journal of Biotechnology and Bioengineering 64 (6): 685-691.

Stenberg, K.; C. Tengborg; M. Gable; G.Zacchi. 1998. Optimisation of Steam Pretreatment of $\mathrm{SO}_{2}-$ Impregnated Mixed Softwoods for Ethanol Production. J Chem Technol Biotechnol. 71:299-308.

Wyman, C.E. 1996. Handbook on Bioetanol: Production and Utilization. Washington: Taylor \& Francis, Ltd.

Yang, B.; E. Wyman. 2005. BSA Treatment to Enhance Enzymatic Hydrolisis of Cellulose in Lignin Containing Substrates. Journal of Biotechnology and Bioengineering 94 (4): 611-617.

M. Daud and Wasrin Syafii

Laboratory of Forest Products Chemistry

Faculty of Forestry

Bogor Agricultural University (IPB)

Tel/Fax : 0251-8621285

E-mail : daud_forest@yahoo.com

Khaswar Syamsu

Agricultural Industry Technology Department

Faculty of Agricultural Industry Technology

Bogor Agricultural University (IPB)

Tel/Fax : 0251- 8621257/0251-8621724

E-mail : khaswars@yahoo.com 